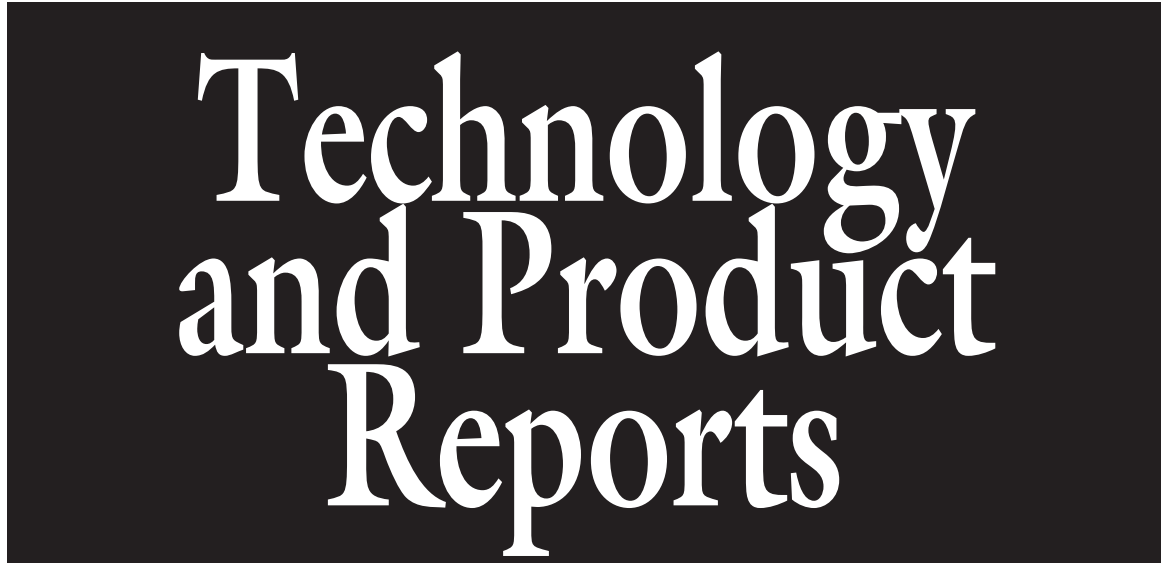

\section{Structure, Function, Application, and Ecological Benefit of a Single-slope, Energy-efficient Solar Greenhouse in China}

\author{
Li-Hong Gao, Mei Qu, Hua-Zhong Ren, Xiao-Lei Sui, \\ Qing-Yun Chen, and Zhen-Xian Zhang ${ }^{1}$
}

ADDITIONAL INDEX wORDs. global climate change, carbon dioxide emissions, $\mathbf{C O}_{2}$, non-transparent insulation materials, back wall thickness, low carbon production, winter vegetables

SUMMARY. Single-slope, energy-efficient solar greenhouses in China use solar energy as the sole source of light and heat for winter crop production in the region between latitudes $32^{\circ} \mathrm{N}$ and $43^{\circ} \mathrm{N}$. The use of solar greenhouses has greatly reduced energy demand and carbon dioxide $\left(\mathrm{CO}_{2}\right)$ emissions. Solar greenhouses are the best structure for growing winter horticultural crops in China, and have been adopted by countries such as Japan, Korea, and Russia. Increased proliferation of efficient solar greenhouses in China may contribute to solving worldwide problems such as the energy crisis and global climate change. This article summarizes the structure, function, application, and ecological benefits of energy-efficient, single-slope solar greenhouses in China, based on 20 years of systematic studies. We hope this technology can be applied to regions of similar climate to help reduce energy consumption and $\mathrm{CO}_{2}$ emissions.

$\mathrm{P}$ rotected horticulture production has a long history in China, and the earliest recordation is written in the Hanshu in the Han Dynasty (206-23 BCE) (Jiang et al., 2004; Zhang, 2005). In recent years, new solar greenhouse technology has been developed in China. These greenhouses play a vital role in China's vegetable production in winter. There are several different types of solar greenhouses, including the single-slope solar greenhouse. These are built facing

College of Agronomy and Biotechnology, China Agricultural University, Beijing 100193, China

This work was supported by the National Key Technologies Research and Development (R\&D) Program of China (2006BAD07B04, 2008BADA6B03), Modern Agro-industry Technology Research System.

${ }^{1}$ Corresponding author. E-mail: Zhangzx@cau.edu.cn. south. The support and insulation walls are on the north, east, and west sides. A short roof is installed on top of the north wall. The south side is supported by metal or bamboo frames or a mixture of both, and is covered with plastic film and an insulating blanket. This type of greenhouse uses solar energy as the sole light and heat source for winter crop production (Figs. IC and 2, A and B) and is unique to northern China. These greenhouses are used to produce warm season crops such as tomato (Solanum lycopersicum) and cucumber (Cucumis sativus) during the winter without using other forms of heat, in locations at latitude $32^{\circ} \mathrm{N}$ to $43^{\circ} \mathrm{N}$.

The light and temperature conditions in solar greenhouses are controlled by solar energy. The feasibility of using such a structure largely depends on the relative duration of sunshine in the winter and the low temperatures at the greenhouse site. Solar greenhouses are widely used in the regions north of Huai River, such as Shandong, Liaoning, Hebei, and Gansu provinces, and the Beijing area. The area encompassed by solar greenhouses in China reached over 0.7 million hectares in $2005(\mathrm{Li}$, 2005 ). The greatest amount of vegetable production using solar greenhouses is in the areas around Bohai Harbor in Shandong, Hebei Province (Chen, 2001; Chen et al., 2007). The major crop species grown are vegetables $(>90 \%)$ and some flowers and fruit trees. Domestic animals were also reported to have been raised in solar greenhouses (Chen et al., 2007; $\mathrm{Li}, 2005)$. Fresh vegetable production during the winter generates significant revenues for the growers $(\mathrm{Li}$, 2006). Vegetables produced in solar greenhouses have been exported to Korea, Japan, Singapore, and several European countries (Chen et al., 2007). The solar greenhouse has a very bright future, especially given the amount of concern over the global energy crisis and climate change (no $\mathrm{CO}_{2}$ emission during horticultural crops winter production), as significant energy savings can be accrued from switching to solar greenhouses. Russia, Japan, and Korea have started to implement this technology.

\begin{tabular}{lllc}
\hline $\begin{array}{l}\text { Units } \\
\begin{array}{l}\text { To convert U.S. to SI, } \\
\text { multiply by }\end{array}\end{array}$ & U.S. unit & SI unit & $\begin{array}{l}\text { To convert SI to U.S., } \\
\text { multiply by }\end{array}$ \\
\hline 0.4047 & $\mathrm{acre}(\mathrm{s})$ & $\mathrm{ha}$ & 2.4711 \\
0.3048 & $\mathrm{ft}$ & $\mathrm{m}$ & 3.2808 \\
0.0929 & $\mathrm{ft}^{2}$ & $\mathrm{~m}^{2}$ & 10.7639 \\
2.54 & inch(es) & $\mathrm{cm}$ & 0.3937 \\
0.4536 & $\mathrm{lb}$ & $\mathrm{kg}$ & 2.2046 \\
4.8824 & $\mathrm{lb} / \mathrm{ft}^{2}$ & $\mathrm{~kg} \cdot \mathrm{m}^{-2}$ & 0.2048 \\
0.9072 & ton $(\mathrm{s})$ & $\mathrm{mg}$ & 1.1023 \\
2.2417 & ton/acre & $\mathrm{mg} \cdot \mathrm{ha}^{-1}$ & 0.4461 \\
$\left({ }^{\circ} \mathrm{F}-32\right) \div 1.8$ & ${ }^{\circ} \mathrm{F}$ & ${ }^{\circ} \mathrm{C}$ & $\left(1.8 \times{ }^{\circ} \mathrm{C}\right)+32$
\end{tabular}


A

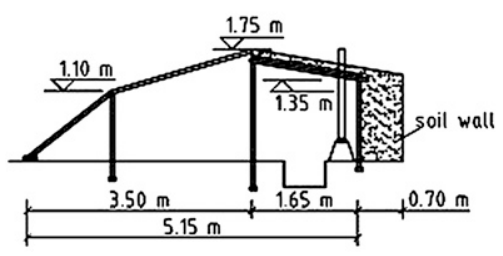

C

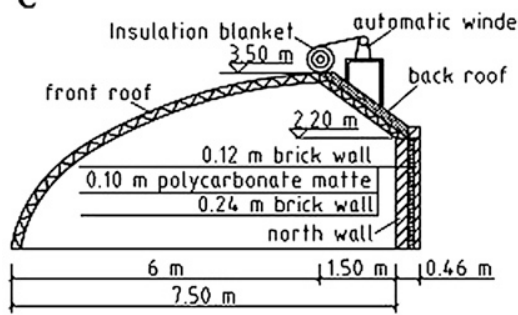

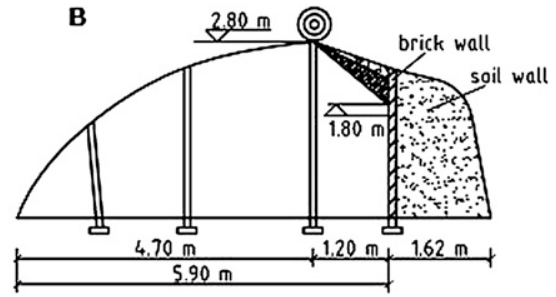

D

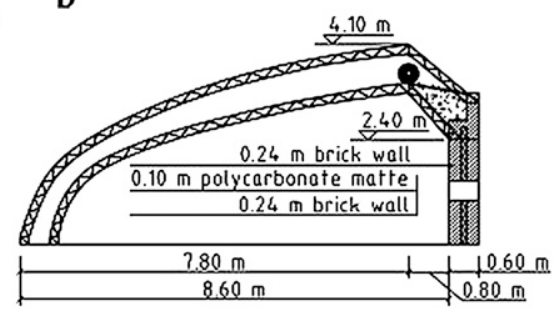

Fig. 1. Models, structure parameters, and evolution of solar greenhouse structure in China. (A) The primary solar greenhouse (before 1985 ): spans $=\mathbf{5 . 5}$ to $6.5 \mathrm{~m}$, wall thickness $=0.5$ to $0.7 \mathrm{~m}$, arch height $=2.1$ to $2.4 \mathrm{~m}$; steel frames and two to three pillars inside the greenhouse, no insulating blanket, the roof is glass. (B) Modified solar greenhouse (1986-95): spans $=6.0$ to $8.0 \mathrm{~m}$, arch height $=3.0$ to $4.0 \mathrm{~m}$; frames are bamboo, steel, or a mixture of both, with two to three pillars inside; soil wall thickness $=0.8$ to $1.1 \mathrm{~m}$ with heterogeneous double layer; transparent coverage materials polyethylene (PE) or polyvinyl chloride (PVC) with insulating blanket on it. (C) Modern solar greenhouse (1996-present): spans $=8.0$ to $14.0 \mathrm{~m}$, arch height $=3.8$ to $5.5 \mathrm{~m}$, walls of air-entrained brick, polystyrene slates, and perlite at $0.8 \mathrm{~m}$; non-pillar, zinc-coated steel frame. The rolling up and down of the insulation blanket and ventilation vents are all automatic. The east and west walls have a wet curtain cooling system. (D) Double-arch solar greenhouse (2007-present): structure parameters are the same as $(\mathrm{C})$ except the double-arch frames; $1 \mathrm{~m}=3.2808 \mathrm{ft}$.
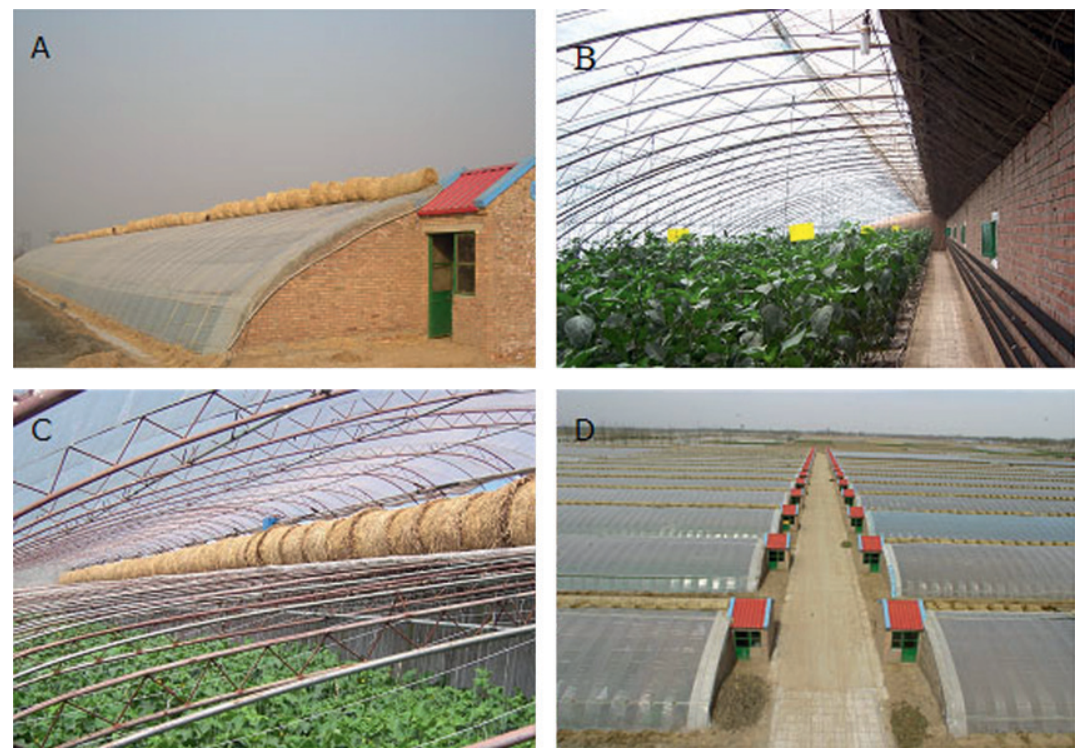

Fig. 2. Photos of a single-slope solar greenhouse: (A) exterior, (B) interior, (C) upper side of the double-arch solar greenhouse, and (D) a group of solar greenhouses. (Photos A through $\mathrm{C}$ were provided by $\mathrm{M}$. $\mathrm{Qu}$ and $\mathrm{Z}$. Zhang, respectively; photo D is courtesy of Beijing Agricultural Bureau).

Through collaboration among Chinese scientists over the last 20 years, much progress in the structure, function, and application of the solar greenhouse has been made toward optimization. The structural design parameters for light harvesting, insulation, as well as crop production techniques, have been defined. A series of solar greenhouse production systems are in place to ensure continuous production of fresh vegetables year round. This article summarizes the status and progress of the structure, function, application, and ecological benefits of single-slope solar greenhouses in China. This technical information may help to guide relevant application in other countries and regions.

\section{Structure and development of single-slope solar greenhouses in China}

Single-slope solar greenhouses were developed from the traditional heated glass greenhouse model, which had mud or brick walls supported by wood frames (Fig. lA). High energy prices have caused a spike in the heating costs associated with traditionally heated greenhouses. In Liaoning Province, China, the first energy-efficient solar greenhouse was built in 1978 . At latitude $40^{\circ} \mathrm{N}$, these greenhouses produced warmseason vegetables without using any heating other than solar radiation (Zhang et al., 2008). This technique spread across the country very rapidly, and later improvement in the structural parameters, and wall and frame materials have led to the improved modern styles (Fig. 1).

The PRIMARY SOLAR GREeNHOUSE. The primary solar greenhouse is the first generation solar greenhouse (Fig. 1A) and its physical parameters are as follows: the span was 5.5 to $6.5 \mathrm{~m}$; the back wall height was 1.4 to $1.7 \mathrm{~m}$ and the thickness was 0.5 to $0.7 \mathrm{~m}$; the arch height was 2.1 to $2.4 \mathrm{~m}$; the angle of elevation of the back roof was $10^{\circ}$ to $15^{\circ}$; and the horizontal shade length of the back roof was 1.0 to $2.0 \mathrm{~m}$ long. Steel frames and pillars were installed inside the greenhouse to support the structure. Glass was the major covering on the roof and the light-harvesting roof had a curved surface. The insulation consisted of non-transparent materials such as straw blankets or bulrush mats. The inner space of the greenhouse was small, and the roof was low. The light-harvesting surface area on the front roof was smaller than modern solar greenhouses, and the small angle of elevation of the back roof resulted in absorption of a very 
limited amount of solar radiation during the winter. The wall and the back roof had a very low capacity for insulating and thermo-protecting. These first greenhouses still needed to be heated by traditional methods to produce warm-season vegetables during the winter. These structures were generally used for early spring production or for the preparation of seedlings on a very small scale.

IMPROVED SOLAR GREENHOUSE. In the late 1980s, an improved style (Fig. 1B) was designed and it has been widely used since then. This type of greenhouse spans 6.0 to $8.0 \mathrm{~m}$, the height of the back wall is 2.0 to $2.8 \mathrm{~m}$ and the arch height is 3.0 to $4.0 \mathrm{~m}$. The angle of elevation of back wall is over $30^{\circ}$, and the horizontal shade length of the back roof is 1.2 to 1.6 $\mathrm{m}$. The thickness of the back roof is $>0.4 \mathrm{~m}$. Soil walls are as thick as the freezing depth, plus $0.5 \mathrm{~m}$. An alternative means of insulation uses the heterogeneous double layer; where outside and inside brick walls are stuffed with 0.5 to $0.8 \mathrm{~m}$ insulating material. Transparent coverage materials include multifunctional polyethylene (PE) or polyvinyl chloride (PVC) films. The light-harvesting surface is shaped as a round arch. The angle of intersection at the bottom of the front roof is $60^{\circ}$ to $65^{\circ}$. Grass insulation pads, straw blankets, and other non-transparent insulation materials on the transparent roof are used to conserve heat after sunset and before sunrise. Cold-proof ditches were dug next to the bottom line of the front roof.

Greenhouse frames can be made from bamboo, steel, or a mixture of both. The structural alterations include changing the angle of elevation of the back roof and the lightharvesting angle of the transparent front roof, and increasing the wall thickness of the side and back walls, as well as the horizontal shade length of the back roof. All of these measures improve light collection and insulation efficiency of the greenhouses. The space inside the greenhouse becomes much more open. These design changes result in energy savings and increased productivity. This style of greenhouse has spread to large areas in northern China, and is presently taking the lead in greenhouse production. An important consideration is that locations at different latitudes vary in sun elevation angle; therefore, the light-harvesting and insulation parameters need to be adjusted accordingly, in that the higher latitudes require a narrower and lower greenhouse structure (Table 1 ).

MODERN SOLAR GREENHOUSE. The improved style of solar greenhouse described above has a low capacity for regulating environmental conditions inside the greenhouse, and there is some difficulty with its mechanical operations. Further technical improvement has led to the modern solar greenhouse (Figs. 1C, and 2, $\mathrm{A}$ and $\mathrm{B}$ ). This style of building spans 8.0 to $14.0 \mathrm{~m}$, the back wall height is 2.5 to $3.5 \mathrm{~m}$, and the arch height is at 3.8 to $5.5 \mathrm{~m}$. The angle of elevation of the back roof is over $35^{\circ}$. The walls incorporate materials with better insulation properties such as air-entrained brick, polystyrene slates, and perlite. The wall thickness is 0.7 to $0.8 \mathrm{~m}$, which makes for a heterogeneous compact wall. The greenhouse frames are non-pillar zinc-coated steel. The

Table 1. The main structural parameters of the solar greenhouse located at different degrees of latitude (Zhang, 2001).

\begin{tabular}{lccccc}
\hline Latitude & $\begin{array}{c}\text { Greenhouse } \\
\text { types }^{\mathbf{z}}\end{array}$ & $\begin{array}{c}\text { Span } \\
(\mathbf{m})^{\mathbf{y}}\end{array}$ & $\begin{array}{c}\text { Ridge } \\
\text { ht }(\mathbf{m})\end{array}$ & $\begin{array}{c}\text { Back wall } \\
\text { ht }(\mathbf{m})\end{array}$ & $\begin{array}{c}\text { Back roof } \\
\text { horizontal shadow } \\
\text { length }(\mathbf{m})\end{array}$ \\
\hline $43^{\circ} \mathrm{N}$ & 1 & 7.0 & $3.5-3.8$ & $2.3-2.5$ & $1.5-1.6$ \\
& 2 & 6.5 & $3.3-3.6$ & $2.2-2.3$ & $1.4-1.5$ \\
$41^{\circ} \mathrm{N}-42^{\circ} \mathrm{N}$ & 3 & 6.0 & $3.0-3.4$ & $2.0-2.2$ & $1.3-1.4$ \\
& 1 & 7.5 & $3.6-3.9$ & $2.3-2.6$ & $1.5-1.6$ \\
$38^{\circ} \mathrm{N}-40^{\circ} \mathrm{N}$ & 2 & 7.0 & $3.4-3.7$ & $2.1-2.4$ & $1.4-1.5$ \\
& 3 & 6.5 & $3.2-3.5$ & $2.0-2.3$ & $1.3-1.4$ \\
& 1 & 8.0 & $3.7-4.0$ & $2.4-2.6$ & $1.4-1.5$ \\
& 2 & 7.5 & $3.5-3.7$ & $2.2-2.5$ & $1.3-1.4$ \\
\hline
\end{tabular}

${ }^{\mathrm{z}}$ Greenhouse types are divided by the span and the ridge height.

${ }^{y} 1 \mathrm{~m}=3.2808 \mathrm{ft}$. light-harvesting roof remains shaped like a rounded arch. The intersection angle at the bottom of the front roof is over $68^{\circ}$. The ventilation vents and rolling up and down of the insulation blanket are controlled automatically. The east and west walls have a wet curtain cooling system, and an external shading system is added for summer cooling. These changes greatly enhance the temperature control capacity of the greenhouse and provide larger spaces and overall better performance. It is beautiful and convenient for management to array many modern solar greenhouses together (Fig. 2D).

At present, solar greenhouses can be categorized according to their structural characteristics: the ordinary style, semiunderground style $(0.5-$ $0.9 \mathrm{~m}$ underground), multiple gutter-connected style, and doublearched style (Figs. ID and 2C). The ordinary style is still the most used version (Fig. 1, B and C), with about $95 \%$ of the extant solar greenhouses using this structure $(\mathrm{Li}, 2005)$. The semiunderground style has a shading problem in winter and waterlogging in summer. The multiple gutterconnected greenhouse style is very roomy, which is often correlated with poor heat preservation if it is not heated. This type of greenhouse is used on a very small scale. The doublearched style is expensive to build ( $\mathrm{Li}$, 2008); however, its good insulation is an attractive attribute. This model is at the beginning stage of technical optimization and extension to end users in the Chinese market.

\section{The main functional characteristics of solar greenhouses}

Light environment. Sunlight provides the sole source of light and heat in the solar greenhouse. The degree of exposure to the sun determines the light conditions inside the greenhouse, which varies according to the season, latitude, greenhouse structure, the aging of plastic film, and the duration of the sunshine. During the winter at high latitudes, there is less solar radiation reaching the greenhouse than in the spring and fall seasons. Areas at lower latitudes are exposed to more optimal light conditions in the winter. Aging of the plastic film reduces its transparency (Zhang, 2001). 
The solar greenhouse has walls on three sides, and only the front roof is exposed to light. The amount of light absorbed is lower than the hoop greenhouse. The areas near the east and west walls form two weak light triangular zones in the morning and afternoon, respectively. All of these factors result in uneven distribution of light in the greenhouse. For example, there is weaker light on the north side than in the middle to south side of the greenhouse, and there is less light at the lower level compared with the upper level. Consequently, the growth of the crops inside the greenhouse is not uniform. Data from several years of studies have demonstrated that in latitudes $32^{\circ} \mathrm{N}$ to $43^{\circ} \mathrm{N}$, the photosynthetic photon flux $(P P F)$ is normally between 450 and $550 \mu \mathrm{mol} \cdot \mathrm{m}^{-2} \cdot \mathrm{s}^{-1}$ on sunny days, but is reduced to 150 and $250 \mu \mathrm{mol} \cdot \mathrm{m}^{-2} \cdot \mathrm{s}^{-1}$ and less on cloudy days during the winter. Low light and temperature during the winter is a major factor limiting crop growth in solar greenhouses.

Temperature environment. The temperature inside the greenhouse is higher than it is outside, and its seasonal changes follow the same pattern as outside. The temperature conditions inside the solar greenhouse favor spring and fall crops. For example, in southern Liaoning Province during the winter (December-February of the next year), the lowest air temperature reaches about -16 to $-20{ }^{\circ} \mathrm{C}$ outside, while inside the temperature can be maintained at above $16{ }^{\circ} \mathrm{C}$ around noon. Internal temperatures rarely fall below $8{ }^{\circ} \mathrm{C}$ inside the solar greenhouse, as measured at daybreak. The temperature difference between inside and outside of the greenhouse can be over $25^{\circ} \mathrm{C}$. In March, as the outside temperature starts to warm up, internal ventilation must be increased and insulation material coverage time must be decreased to reduce the temperature gradient between the inside and outside of the greenhouse. From June to all the summer months, temperatures remain similar inside and outside the greenhouse because transparent materials on the roof are opened. The pattern of temperature variation inside solar greenhouse in other provinces or regions is similar to Liaoning province.

The diurnal temperature changes inside the greenhouse are similar to outside temperatures (i.e., higher during the day and lower at night). But the diurnal fluctuation is greater inside the greenhouse, especially during sunny winter days. In the morning, after $0830 \mathrm{HR}$, the temperature inside the greenhouse rises rapidly and reaches the highest level around $1300 \mathrm{HR}$, and then drops to the lowest level by day break (Fig. 3). Internal high temperatures can be above $32{ }^{\circ} \mathrm{C}$ on sunny winter days or as low as $15{ }^{\circ} \mathrm{C}$ on cloudy days. The diurnal temperature fluctuation is affected by weather conditions and can be about 10 to $18^{\circ} \mathrm{C}$ on cloudy days, or as high as 25 to $32{ }^{\circ} \mathrm{C}$ on sunny days. Years of data show that in most areas where solar greenhouses have been built with heterogeneous wall materials $(0.8 \mathrm{~m}$ thick) or mud walls $(1.2-1.5 \mathrm{~m}$ thick), the lowest internal temperature reached is 5 to $8{ }^{\circ} \mathrm{C}$ when the temperature outside greenhouse was about $-15{ }^{\circ} \mathrm{C}$. The most extreme lows stay above $5{ }^{\circ} \mathrm{C}$ at daybreak, and only for a short time, which would not cause injury to the warm season crops. Under the influence of the uneven light distribution, the room temperature inside the solar greenhouse is not uniform either. During the day, the air temperature is usually higher at the upper level than at the lower level, and the middle of the greenhouse temperature is higher than at the edges. At night, the front roof loses heat faster than the back wall, creating a warmer area on the north side than the south side of the greenhouse. The horizontal temperature variation inside the greenhouse is about 3 to $4{ }^{\circ} \mathrm{C}$, and the vertical gradient is 2 to $3^{\circ} \mathrm{C}$. Smaller greenhouses tend to have more areas with low temperature and more unevenness in terms of temperature distribution (Zhang, 2001). Inside the solar greenhouse, the top 20 to $25 \mathrm{~cm}$ layer of soil has obvious seasonal and diurnal fluctuations, albeit to a much lesser extent than the air temperature. During the winter in Shandong province, soil temperature in the top 15 $\mathrm{cm}$ depth is maintained at 17 to $20^{\circ} \mathrm{C}$ during the day and at 15 to $18{ }^{\circ} \mathrm{C}$ at night. Due to the impact of heat exchange, temperatures at the edges are lower than the middle of the greenhouse.

OTHER ENVIRONMENTAL FACTORS. Solar greenhouses are near airproof or semisealed. Moisture from soil evaporation and plant transpiration is hard to dissipate, resulting in higher relative humidity $(\mathrm{RH})$ inside the greenhouse. In winter when there is very little ventilation, the internal RH can reach over $90 \%$, which is much higher than in heated greenhouses. It is disadvantageous in preventing crop diseases. Solar greenhouses are

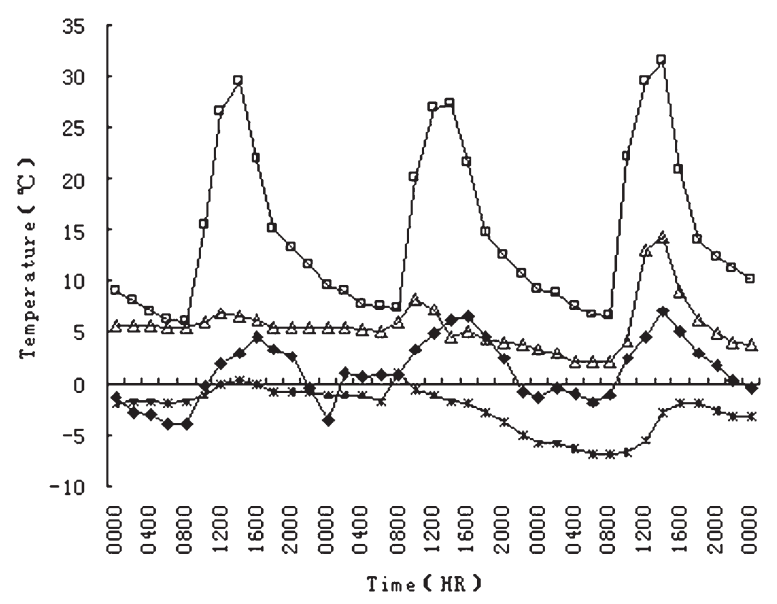

Fig. 3. Daily temperature changes in successive sunny days and cloudy days inside and outside of a solar greenhouse in January in Beijing, China (lat. $40^{\circ} \mathrm{N}$ ) (Zhang et al., 2008). Daily temperature changes in successive sunny days ( $-\square-$ ) and in successive cloudy days $(-\triangle-)$ inside the greenhouse. Daily temperature changes in successive sunny days (- - - $)$ and in successive cloudy days $\left({ }^{*}-\right)$ outside of the greenhouse. Greenhouse style: modern $\operatorname{span}=8.0 \mathrm{~m}(1 \mathrm{~m}=3.2808 \mathrm{ft})$, west-east length $=60 \mathrm{~m}$, roof peak height $=3.8 \mathrm{~m}$, heterogeneous compacted material wall thickness $=0.8 \mathrm{~m}$. The observation site was the middle of the greenhouse $(3.5 \mathrm{~m}$ from the front of the greenhouse and $1.5 \mathrm{~m}$ from the ground level $) ;\left(1.8 \times{ }^{\circ} \mathrm{C}\right)+32={ }^{\circ} \mathrm{F}$. 
more prone to accumulating ammonia $\left(\mathrm{NH}_{3}\right)$ from large amounts of ammonium $\left(\mathrm{NH}_{4}\right)$ fertilizers and compost in the soil, and other toxic gases. In the production season, it is very important to control moisture and toxic gases through appropriate ventilation management (Zhang et al., 2008).

\section{Application and benefits of the solar greenhouse}

Horticultural CROPS GROWING IN THE SOLAR GREENHOUSE. Presently, solar greenhouses are used for producing a continuous supply of fruit vegetables for winter and spring markets. In recent years, a wider range of products, including edible fungi, flowers (potted and cut flowers), and fruit [e.g., wine grape (Vitis vinifera), peach (Prunus persica), papaya (Carica papaya)] have been grown in solar greenhouses. Production of seedlings, herbal plants, and domestic animals are the newer applications of solar greenhouses.

VEGETABLE PRODUCTION SEASONS AND KEY TECHNIQUES IN SOLAR GREENHOUSE USAGE. Vegetables can be grown in solar greenhouses year round. Plant types with short growing periods can be sown at anytime, based on market demands. For those types with long growth periods that require larger areas to grow in, such as cucumber and tomato, a twoseason growth cycle is recommended (the fall-winter from August to January of next year, and the winter-spring from January to June), or use one long season of these crops (from August to June of next year).

In recent years, a series of growing techniques for improving greenhouse productivity has been identified according to the characteristics inside solar greenhouses [i.e., less radiation (weak light), low temperature, and high humidity]. These techniques include: 1) use vegetable varieties that are tolerant to weak light, low temperature, and other stresses [e.g., many varieties of cucumber, tomato, and pepper (Capsicum annuиm) perform well in the greenhouse]; 2) sow seeds on time, expand the row spacing to reduce the density of plants, and prune the plants; 3 ) use plastic film mulch and underground drip irrigation to control air humidity and reduce diseases; 4) apply organic fertilizer to increase soil temperature, improve soil physical and chemical status, and to correct for $\mathrm{CO}_{2}$ deficiency; 5 ) use non-drop, highinsulation transparent coverage materials to improve light transmission; and 6) manage the ventilation properly to control diseases. Using these techniques, the yields of tomato, $\mathrm{Cu}^{-}$ cumber, and eggplant (Solanum melongena) crops have reached 30,28 , and $27 \mathrm{~kg} \cdot \mathrm{m}^{-2}$, respectively $(\mathrm{Li}$, 2005).

ECONOMIC AND ECOLOGICAL BENEFITS OF THE SOLAR GREENHOUSE. In the same region and under the same production system, solar greenhouses are significantly better in productivity efficiency and the ratio of input/output than the heated greenhouse (Table 2). The annual net income average is about 25 yuan $/ \mathrm{m}^{2}$, or even more, for the solar greenhouse. The profit from a solar greenhouse was 10 to 15 times higher than field vegetable production, and 70 to 125 times higher than growing corn (Zea mays) and wheat (Triticum aestivum) crops (Li, 2005). Vegetable production from solar greenhouses is one of the most important approaches to enriching farmers in the country. These economic advantages only apply to certain styles of greenhouses. The large gutter-connected heated greenhouse is much more costly to build and has higher depreciation, and the additional heating costs have led to a lower output/ input ratio and greater deficit each year (Table 2). This type of greenhouse is not suitable for developing countries.

The ecological benefits of solar greenhouse production in China are enormous. Because no heating is required in winter, the solar greenhouse saves an average of $750 \mathrm{Mg} \cdot \mathrm{ha}^{-1} \mathrm{coal}$

Table 2. Input and output of different styles of greenhouses for growing cucumber and tomato in Beijing, China.

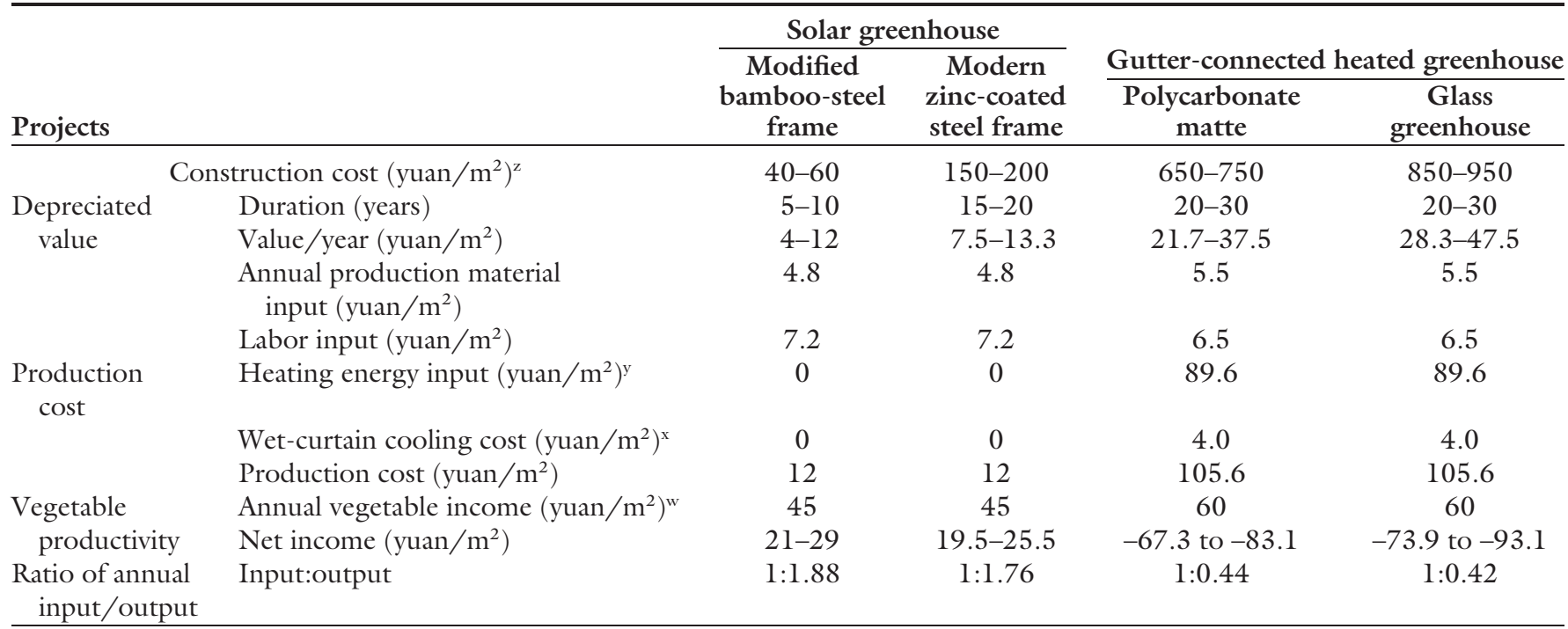

${ }^{\mathrm{z}} 1$ yuan $/ \mathrm{m}^{2}=\$ 0.1465 / \mathrm{m}^{2}=\$ 0.0136 / \mathrm{ft}^{2}$

${ }^{y}$ Heating cost was calculated by assuming that the gutter-connected greenhouse needs to be heated $100 \mathrm{~d}$ in winter, and needs burn $1.12 \mathrm{~kg} \cdot \mathrm{m}^{-2}\left(0.229 \mathrm{lb} / \mathrm{ft}^{2}\right)$ of coal per day at unit price of 0.80 yuan $/ \mathrm{kg}(\$ 0.1172 / \mathrm{kg}, \$ 0.0532 / \mathrm{lb})$.

${ }^{x}$ Cooling cost was calculated by assuming that the gutter-connected greenhouse needs to be cooled $100 \mathrm{~d}$ in summer, and needs consume $0.4 \mathrm{~kW} \cdot \mathrm{m}^{-2}\left(0.037 \mathrm{~kW} / \mathrm{ft}^{2}\right)$ of electricity per day at unit price of 0.80 yuan $/ \mathrm{kW}(\$ 0.1172 / \mathrm{kW})$.

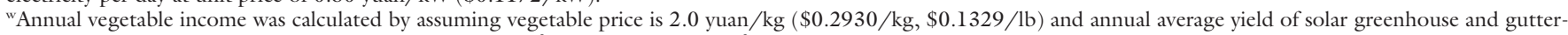
connected greenhouse in 3 years was 22.5 and $30.0 \mathrm{~kg} \cdot \mathrm{m}^{-2}\left(4.61\right.$ and $\left.6.14 \mathrm{lb} / \mathrm{ft}^{2}\right)$, respectively. 
compared with the heated greenhouse. Currently, there are more than 0.74 million hectares of solar greenhouses in China (Liu and Zou, 2007; Zhang, 2009). This could save 500 million megagrams of coal, or onefifth of the total coal consumption in the nation. $\mathrm{CO}_{2}$ emissions could be reduced by 300 million megagrams ( $\mathrm{Li}, 2005)$. Overall, the energy-saving and pollution reduction effect is tremendous.

\section{Conclusions and recommendations}

The solar greenhouse is an important innovation in protected cultivation history, especially in this low carbon production era. It has many advantages in that they save energy, reduce pollution, and improve economic and social development. However, solar energy can be adversely affected by weather conditions. During winter, the less solar radiation and low temperatures can have significantly negative impact on warm-season vegetable productivity of the greenhouses, and addressing this remains a very challenging task. Innovation and optimization of the greenhouse structure needs to continue. More work needs to be done on gutter-connected, double-arched, and semiunderground greenhouses. New wall insulation materials need to be developed to reduce the thickness of the wall while improving its insulation efficiency and expanding space utilization. Also, new varieties should be bred for horticultural crops that can adapt to low light and temperature conditions in solar greenhouses in winter. Implementation of these measures will provide a solid foundation that will ensure sustainable development of the greenhouse industry.

Solar greenhouses have proven to be energy efficient, and they decrease $\mathrm{CO}_{2}$ emissions and yield high profits. They have become the most important type of infrastructures for growing horticultural crops in China. Today, the world is facing an energy crisis and "global warming," and using solar greenhouses can help curb these problems. We hope that this technology can be adopted by developing and developed nations and regions of similar climate.

\section{Literature cited}

Chen, D.S. 2001. Distinct and climate must be considered in solar greenhouse building. China Flowers Hort. 13:8-9 (In Chinese).

Chen, M.S., S.P. Ma, P.G. Zhou, and J.W. Li. 2007. Promoting modern vegetable production by implementation of an exportation policy. China Veg. 2007:1-4 (In Chinese).
Jiang, W.J., D.Y. Qu, D. Mu, and L.R. Wang. 2004. Protected cultivation of horticultural crops in China. Hort. Rev. (Amer. Soc. Hort. Sci.) 30:115-162.

Li, C.S. 2008. Structure and function of single slope energy efficient solar greenhouse of "jichun type." China Veg. 2008:49-51. (In Chinese).

Li, J.W. 2006. The reviewing of vegetable production in 2005 in China. China Veg. 2006:1-2. (In Chinese).

Li, T.L. 2005. Current situation and prospects of green house industry development in China. J. Shenyang Agr. Univ. 36:131-138. (In Chinese).

Liu, J. and C.J. Zou. 2007. The present and development of sunlight greenhouse structure optimization. J. Inner Mongolia Agr. Univ. (Natural Sci.) 3:89-92. (In Chinese).

Zhang, F.M. (ed.). 2001. Protected horticulture. China Agricultural University Press, Beijing. (In Chinese).

Zhang, X.H., Q.Y. Chen, M. Qv, and F. Yu. 2008. Heating effects of source heat pump on sun-light greenhouse. J. Shanghai Jiao Tong Univ. (Agr. Sci.) 26: 436-439. (In Chinese).

Zhang, Z.H. 2009. Questions and countermeasure during protected vegetable production in China. China Veg. 2009: 1-3. (In Chinese).

Zhang, Z.X. (ed.). 2005. Vegetable cultivation. China Agricultural University Press, Beijing. (In Chinese). 